Original Research Paper

\title{
Pengembangan Fenomena dan Soal Multi Jawaban untuk Pembelajaran Kausalitik Dalam Meningkatkan Kemampuan Pemecahan Masalah dan Berpikir Kreatif Siswa
}

\author{
Ahmad Harjono ${ }^{1,2}$, Joni Rokhmat ${ }^{1,2^{*}}$, Hikmawati ${ }^{1}$, Syahrial Ayub $^{1}$, Ap'aludin ${ }^{1}$, Nada Khalid ${ }^{1}$ \\ ${ }^{1}$ Program Studi Pendidikan Fisika, FKIP, Universitas Mataram, Mataram, Indonesia; \\ ${ }^{2}$ Program Studi Magister Pendidikan IPA, Pascasarjana, Universitas Mataram, Mataram, Indonesia.
}

https://doi.org/10.29303/jpmpi.v3i2.1202

Sitasi: Harjono, A., Rokhmat, J., Hikmawati., Ayub, S., Ap'aludin \& Khalid, N. (2021). Pengembangan Fenomena dan Soal Multi Jawaban untuk Pembelajaran Kausalitik Dalam Meningkatkan Kemampuan Pemecahan Masalah dan Berpikir Kreatif Siswa. Jurnal Pengabdian Magister Pendidikan IPA 4(4)

\section{Article history}

Received: 10 Oktober 2021

Revised: 30 Oktober 2021

Accepted: 17 November 2021

*Corresponding Author: Joni Rokhmat, Universitas

Mataram, Mataram, Indonesia; Email: joni.fkip@unram.ac.id

\begin{abstract}
Fenomena dan soal multi jawaban dikembangkan khususnya untuk pembelajaran model kausalitik. Tujuan kegiatan adalah desiminasi kerangka konseptual pengembangan fenomena dan soal multi jawaban untuk peningkatan kemampuan pemecahan masalah dan berpikir kreatif siswa. Kegiatan dilakukan secara online menggunakan media zoom seiring dengan masih diberlakukan PPKM di era pandemic Covid-19 dengan peserta sesuai keterjankauan. Diperoleh 35 peserta yang terdiri atas alumni (guru dan dosen) dan mahasiswa tingkat atas program studi pendidikan fisika, FKIP Universitas Mataram. Instrumen digunakan terdiri dari media elektronik zoom dan angket, serta materi pengembangan fenomena dan soal multi jawaban. Hasil kegiatan memperlihatkan bahwa dari delapan indikator angket, peserta cendrung bersikap setuju (25\%) dan sangat setuju (75\%) terhadap setiap pernyataan positif angket. Rekomendasi bersama tim dan peserta menyatakan bahwa pengembangan fenomena dan soal multi jawaban: 1) sejalan dengan pembelajaran dengan orientasi penguasaan konseptual, 2) sangat perlu dikembangkan secara lateral (semua disiplin ilmu) maupun vertikal (semua jenjang pendidikan), 3) mendorong pengembangan kemampuan pemeacahan masalah dan berpikir tingkat tinggi, 4) berpikir tingkat tinggi perlu diberikan kepada siswa sedini mungkin dan dijadikan sebagai pembiasaan dalam setiap pembelajaran.
\end{abstract}

Keywords: Fenomena dan soal multi jawaban, model kausalitik, penuasaan konseptual, kemampuan pemecahan masalah, berpikir tingkat tinggi.

\section{Pendahuluan}

Pelaksanaan pembelajaran fisika dan sarana buku pendukung, secara umum lebih mengedepankan paparan persamaan matematis yang popular sebagai rumus fisika. Selain itu, persoalan atau soal fisika yang dibuat secara umum mengikuti pola hubungan kausal divergen, yaitu dua atau lebih faktor penyebab (variabel bebas) menghasilkan sebuah akibat (variabel terikat) (Rokhmat, 2017, 2018, 2019, \& 2020).

Dasi sudut pandang ketercapaian tujuan pembelajaran, pembahasan melalui pendekatan 
persamaan matematika cenderung menghasilkan ketercapaian tujuan lebih rendah daripada pembahasan dengan pendekatan konseptual. Ketercapaian secarra tuntas untuk pembahasan fisika dengan pendekatan pertama adalah semu. Hal ini dikarenakan ukuran tuntas atau capaian nilai yang baik atau bahkan sangat baik adalah hasil pengukuran menggunakan alat ukur yang juga cenderung menggunakan persamaan matematika dengan porsi yang besar. Sebaliknya, pendekatan ini sangat minim membahas konsep fisika. Hakekatnya, pembelajaran fisika yang dominan menempatkan persamaan matematis yang biasa disebut sebagai rumus fisika, adalah bukan pembahasan fisika sesungguhnya tetapi lebih ke arah pembahasan disiplin ilmu matematika.

Indikator pembahasan konseptual itu sendiri, tim pengabdian memaknai sebagai pembahasan fisika yang lebih menekankan hubungan fungsional (non matematis, atau non rumus) antara saru besaran dengan besaran lainnya. Sebagai contoh, saat membahas pembiasan cahaya oleh permukaan batas dua medium tidak menekankan pada persamaan matematis yang menghubungkan kerapatan medium dengan nilai sudut datang dan sudut bias cahaya terebut.

Dalam fenomena pembiasan di atas, pembahasannya lebih menekankan pada pengertian arah rambat sinar sebagai arah rambat muka gelombang. Kemudian ketika cahaya datang membentuk sudut lancip, maka titik-titik pada salah satu sisi muka gelombang yang datang dari medium pertama akan lebih dulu pindah ke medium kedua dibandingkan titik pada sisi muka gelombang lainnya. Apabila medium kedua lebih rapat maka titik-titik pada muka gelombang yang sudah berada pada medium pertama akan bergerak lebih lambat dibandingkan titik-titik pada muka gelombang yang masih berada di medium pertama. Peristiwa ini menyebabkan ada pembelokan muka gelombang. Jika cahaya itu sejajar maka muka gelombangnya adalah berupa garis lurus dan setelah memasuki medium kedua garis muka gelombang akan mengalami pembelokan yang membentuk sudut lebih kecil terhadap permukaan batas dibandingkan garis muka gelombang ketika semua ada di medium pertama.

Dengan dasar model pembahasan di atas, pembahasan fisika benar-benar mengarah pada pembahasan konseptual. Penggunaan persamaan matematik atau dikenal rumus fisika hanya untuk menguatkan pemahaman konsep fisika tersebut. Jangan dibalik, jika diawali dengan pembasan persamaan matematik maka selanjutnya pembahasan konseptual akan sangat sulit diberikan. Sejalan dengan penjelasan tentang pembahasan fisika secara konseptual di atas, tim pengabdian mencoba mengintegrasikan pembelajaran berbasis pembahasan konseptual ini kedalam model pembelajaran kausalitik. Secara umum, model pembelajarn kausalitik menekankan penggunaan fenomena maupun soal yang berbasia model kausal divergen atau gabungan. Intinya adalah bahwa dalam fenomena maupun soal yang digunakan memiliki dua atau lebih potensi jawaban. Dangan intrumen model ini, mahasiswa atau siswa dilatihkan memiliki kemampuan memecahkan masalah fisika serta kemampuan berpikir kreatif.

Pemecahan masalah adalah kemampuan untuk memilih atau secara deduktif memprediksi berbagai kemungkinan konsekuensi dari fenomena fisik, yang mengandung satu atau beberapa penyebab tertentu, dan dapat menjelaskan bagaimana penyebab tersebut menghasilkan efek yang dipilih (Rokhmat, 2013, 2018, 2020). Kemampuan pemecahan masalah juga terkait dengan kreativitas seseorang. Kreativitas dapat dijelaskan sebagai segala sesuatu yang dihasilkan oleh manusia yang menggunakan pemikiran dan energi fisik secara terus menerus dan berguna untuk memecahkan masalah yang dihadapi (Makmur \& Thahier, 2015: 44)). PSA dan kreativitas sangat dibutuhkan dalam proses pembelajaran (Sambada, 2012), khususnya pelajaran fisika.

Berdasarkan hasil studi awal melalui interaksi formal dalam kegiatan perkuliahan fisika dasar maupun perkuliahan lainnya, serta dalam proses ujian proposal maupun skripsi diperoleh informasi bahwa secara umum kemampuan pemecahan masalah mahasiswa dan kemampuan berpikir kreatifnya masih belum mencapai kategori yang diharapkan. Hal ini ditunjukkan ketidakmampuan mahasiswa menjawab atau menyelesaikan permasalahan terkait konsep fisika juga ketika menjawab pertanyaan yang bekaitan dengan kemampuan berpikir kreatif. Selain itu, dalam perkuliahan fisika, masih banyak para pendidik yang mendasarkan pada rumus-rumus fisika dengan porsi yang jauh lebih besar daripada konsep. Data lainnya, bahwa hampir tidak ada buku rujukan dan pendidik penyelenggara perkuliahan yang mengutamakan penggunaan fenomena 
maupun persoalan yang mengarah pada multi jawaban.

Sesuai dengan paparan di atas, maka dalam kegiatan pengabdian ini dirumuskan tiga masalah sebagai berikut:

1. Bagaimanakah melatihkan para mahasiswa senior dan lulusan dalam mengembangkan fenomena maupun soal berbasis multi-jawaban benar?

2. Bagaimanakah respon mahasiswa senior dan lulusan terhadap upaya pengembangan dan implementasi fenomena dan soal multijawaban benar?

3. Bagaimanakah strategi pengembangan fenomena maupun soal multi jawaban benar?

Tujuan pengabdian pada masyarakat ini adalah:

1. Mengidentifikasi kemampuan mahasiswa senior dan lulusan dalam mengembangkan fenomena dan soal multi-jawaban benar,

2. Mengidentifikasi respon mahasiswa senior dan lulusan terhadap upaya pengembangan dan implementasi fenomena dan soal multijawaban benar, dan

3. Melatihkan strategi respon mahasiswa senior dan lulusan terhadap upaya pengembangan dan implementasi fenomena dan soal multijawaban benar.

Kegiatan pelatihan ini diharapkan dapat memberikan manfaat, bagi mahasiswa senior dan lulusan, seperti:

1. Mampu mengembangkan sendiri fenomena dan soal multi-jawaban benar,

2. Dapat mengimplementasikan fenomena dan soal multi-jawaban benar dalam pembelajaran fisika dengan model kausalitik, dan

Membiasakan mahasiswa senior dan lulusan program studi pendidikan fisika untuk mengembangkan dan menggunakan fenomena dan soal multi-jawaban benar, serta mengintegrasikannya dalam pembelajaran model kausalitik.

\section{Metode}

\section{Tahapan Pemecahan Masalah}

Untuk memecahkan masalah di atas perlu diadakan pengabdian kepada mahasiswa dan alumni pendidikan fisika sebagai mitra tentang pengembangan fenomena dan soal multi-jawaban. Dalan pengabdian ini diawali dengan analisis situasi calon partisipan kemudian dilanjutkan dengan kegiatan identifikasi materi fisika, identifikasi strategi fenomena dan soal multijawaban yang berpotensi dikembangkan, pengembangan fenomena dan soal multi-jawaban, implementasi fenomena dan soal multi-jawaban, dan terakhir dilakukan evaluasi hasil kegiatan. Secara rinci, tahapan pemecahan masalah adalah sebagai tersebut

Kondisi saat ini: 1) Fenomena dan soal multijawaban belum banyak dikenal dan dipahami guru; 2) Partisipan belum mampu mengembangkan Fenomena dan soal multijawaban untuk pembelajaran fisika' 3) Partisipan belum pernah atau tidak terbiasa menggunakan fenomena dan soal multi-jawaban dalam pembelajaran fisika; Kegiatan: 1) Dilakukan sosialisasi tentang fenomena dan soal multi-jawaban sebagai strategi alternatif untuk pembelajaran fisika; 2) Paparan strategi mengembangkan fenomena dan soal multijawaban untuk pembelajaran fisika; 3) Diperagakan penggunaan fenomena dan soal multi-jawaban dalam pembelajaran; Kondisi yang diharapkan: 1) Partisipan memiliki pengetahuan adanya fenomena dan soal multijawaban dan menyadari pentingnya digunakan dalam pembelajaran fisika; 2) Partisipan dapat mengembangkan fenomena dan soal multijawaban untuk setiap materi pembahasan fisika; 3) Partisipan dapat mengimplementasikan fenomena dan soal multijawaban dalam pembelajaran fisika.

\section{Khalayak Sasaran Antara yang Strategis}

Kegiatan pengabdian pada masyarakat ini melibatkan semua mahasiswa senior dan alumni program studi pendidikan fisika FKIP Universitas Mataram. Adapun yang menjadi sasaran kegiatan pengabdian adalah para mahasiswa senior dan alumni sesuai keterjangkauan hasil sosialisasi melalui media sosial.

\section{Kriteria Kegiatan}

Dilematika kualitas pendidikan fisika sudah semestinya tidak hanya dipikirkan oleh pihak mahasiswa calon guru fisika saja atau alumni pendidikan fisika secara umum, tetapi menjadi permasalahan semua unsur yang terkait, seperti PEMDA setempat, pihak sekolah, dan perguruan tinggi sebagai penghasil tenaga pendidik maupun kependidikan. Kualitas pendidikan fisika juga dapat ditingkatkan melalui kegiatan pengabdian pendidikan dan publikasi ilmiah pada jurnal lokal, 
nasional belum terakreditasi, nasional terakreditasi, dan/atau jurnal internasional, serta sosialisasi secara langsung terhadap subjek sasaran, dalam hal ini mahasiswa senior dan alumni melalui kegiatan pengabdian. Selanjutnya, kegiatan pengabdian ini juga bermanfaat bagi mahasiswa senior dan alumni untuk membangkitkan gagasannya dalam pengembangan keprofesian berkelanjutan (PKB) untuk memulai melakukan kegiatan pengabdian, khususnya pembelajaran. Suasana kerjasama secara melembaga juga perlu diwujudkan dengan jangkauan sasaran yang lebih luas. Melalui pengabdian ini, diharapkan pula terjalin kerjasama yang semakin baik antara FKIP Universitas Mataram dengan Penyelenggara pendidikan pada jenjang menengah atas, khususnya para guru SMAN/MA di provinsi Nusa Tenggara Barat.

\section{Metode Kegiatan}

Pengabdian ini menggunakan metode ceramah, tanya-jawab, dan peragaan tentang pengenalan, pengembangan, dan penggunaan fenomena dan soal multi-jawaban untuk pengembangan pendidikan fisika di SMA/MA secara umum.

\section{Evaluasi}

Evaluasi ditujukan untuk memanfaatkan informasi yang diperoleh sebagai acuan dalam menentukan kegiatan selanjutnya. Evaluasi ini direncanakan dilakukan pada bagian proses pelaksanaan dan bagian akhir kegiatan dengan cara mengidentifikasi respon partisipan, serta efektivitas dan efisiensinya penggunaan fenomena dan soal multi-jawaban. Evaluasi tentang respon guru dan siswa dijaring menggunakan open-ended question sehingga selain diperoleh informasi yang sudah diarahkan juga didapatkan pendapat partisipan dalam sudut pandang yang lebih terbuka.

\section{Hasil dan Pembahasan}

Hasil Kegiatan: Kegiatan pengabdian ini dilaksanakan pada masa Pandemi Covid-19 sehingga dengan pertimbangan keharusan mencegah potensi penyebaran Covid-19 tersebut maka prosesnya dilakukan secara online menggunakan fasilitas Zoom. Sebagai sasaran peserta adalah mahasiswa tahun akhir dan alumni pendidikan fisika Universitas Mataram. Mengingat berbagai keterbatasan seiring penggunaan media zoom, seperti ketersediaan kuota internet, kekuatan jaringan internet di tempat calon peserta berada, hingga kendala cuaca yang seringkali menghambat kelancaran internet, maka sebagai peserta dalam kegiatan ini adalah berdasarkan keterjangkauan. Hasilnya, didapat sebanyak 35 peserta yang terdiri dari empat mahasiswa program studi pendidikan fisika tahun akhir dan 31 alumni program studi pendidikan fisika yang lokasinya tersebar di berbagai tempat di wilayan Provinsi Nusa Tenggara Barat (NTB) yang secara umum berprofesi sebagai guru SMA, SMK, baik negeri maupun swasta, serta sebagai guru MTs

Pembahasan hasil kegiatan pengabdian akan difokuskan pada respon para peserta terhadap hasil kegiatan pengabdian ini. Hasil respon langsung meliputi sikap peserta terhadap setiap pernyataan angket yang terbagi kedalam delapan indikator, yaitu: (1) pengetahuan fenomena dan soal multi jawaban (Indikator-1; $P-1$ dan $P-2$ ), (2) keterkaitan fenomena dan soal multi jawaban dengan potensi pengembangan kemampuan berpikir tingkat tinggi (Indikator-2; $P-3$ dan $P-9$ ), (3) keterkaitan fenomena dan soal multi jawaban dengan penguasaan konsep (Indikator-3; $P-4$ ), (4) kesulitan peserta dalam mengembangkan fenomena maupun soal multi jawaban sebelum mengikuti kegiatan (Indikator-4; $P$-5), (5) efektivitas kegiatan pengabdian dalam menyampaikan strategi pengembangan fenomena maupun soal multi jawaban (Indikator-5; $P-6, \quad P-7, \quad \& \quad P-8), \quad(5)$ persetujuan peserta bahwa fenomena dan soal multi jawaban sebaiknya dikembangkan untuk semua jenjang pendidikan (Indikator-6; P-10), (6) persetujuan peserta bahwa berpikir tingkat tinggi seharusnya diberikan kepada siswa sedini mungkin (Indikator-7; $P-11$ ), serta (7) berpikir tingkat tinggi harus menjadi pembiasaan bagi seluruh siswa pada semua jenjang pendidikan (Indikator-8; $P$-12).

Simbol $P$ dalam paparan di atas menyatakan "pernyataan" sedangkan simbol " $P$-x" berarti "pernyataan ke- $x$ ". Jadi dalam pengabdian ini, untuk mengumpulkan data respon peserta digunakan 12 pernyataan.

Analisis data angket menggunakan skala Likert untuk kuantisasi pernyataan sikap responden. Sikap "Sangat Setuju" diberi skor 4, "Setuju" diberi skor 3, "Tidak Setuju" diberi skor 2, dan sikap "Sangat Tidak Setuju" diberi skor 1. Selanjutnya hasil konversi pernyataan sikap kedalam skor tersebut dianalisis secara deskriptif. Hasilnya yaitu 
skor sikap responden berada pada nilai 3,21 (indikator ke-5) hingga 3,69 (indikator ke-8), sementara skor rata-rata seluruh angket adalah 3,45.

Pembahasan: Kehadiran tim pengabdian dalam upaya membantu mahasiswa program studi pendidikan fisika tingkat atas beserta alumni dalam memperkenalkan kerangka konseptual pengembangan fenomena dan soal multi jawaban mendapat respon yang sangat positif, khususnya dalam upaya meningkatkan kemampuan berpikir tingkat tinggi bagi pebelajar. Secara umum, dengan persentase yang sangat tinggi menyatakan setuju (skor 3) hingga sangat setuju (skor 4) terhadap setiap pernyataan positif terkait pengembangan fenomena dan soal multi jawaban tersebut (Tabel 4.2).

Jika skor angket dilakukan pendekatan ke skor 4 atau ke 3 , didapat dua indikator respon terhadsap pernyataan pengembangan fenomena dan soal multi jawaban yang pendekatannya menuju skor 3 (indikator 1 dan 5) sedangkan enam lainnya menuju skor 4 (indikator 2, 3, 4, 6, 7, \& 8) (ibid). Dengan kata lain, $25 \%$ peserta pengabdian menyatakan setuju dengan deskriptor pada indikator pernyataan terkait pengembangan fenomena dan soal multi jawaban dan sisanya, $75 \%$, menyatakan sangat setuju.

Jika diurutkan dari kecenderungan sikap "Sangat Setuju" hingga "Setuju" terhadap isi setiap pernyataan terkait pengembangan fenomena dan soal multi jawaban untuk pembelajaran fisika dengan model kausalitik maka dapat disusun respon peserta sebagai berikut:

1. Setelah mengikuti penjelasan, saya merasa dapat menyusun fenomena multi-akibat maupun soal multi-jawaban (indikator 8)

2. Mengerjakan soal yang memiliki lebih dari satu jawaban benar disertai alasan sangat cocok digunakan untuk meningkatkan penguasaan konsep fisika (indikator 3)

3. Sebelum mengikuti pelatihan peserta mengalami kesulitan menyusun fenomena multi-akibat maupun soal multi-jawaban (indikator 4)

4. Penggunaan fenomena multi-akibat dan soal multi-jawaban sangat cocok untuk mengembangkan kemampuan berpikir kreatif dan berpikir kritis (indikator 2)

5. Secara umum fenomena multi-akibat maupun soal multi-jawaban sangat cocok digunakan pengembangan berpikir tingkat tinggi
6. Fenomena multi-akibat maupun soal multijawaban sebaiknya dikembangkan bukan hanya untuk mahasiswa tetapi juga untuk siswa pada semua jenjang (indikator 6)

7. Berpikir tingkat tinggi sebaiknya dilatihkan kepada siswa sedini mungkin (indikator 7)

8. Sebelum mengikuti pelatihan saya belum tahu apa yang dimaksud fenomena multi-akibat maupun soal multi-jawaban (indikator 1)

9. Setelah mengikuti pelatihan saya memandang bahwa pengembangan fenomena multi-akibat dan soal multi-jawaban sangat diperlukan dalam pembelajaran

10. Dalam pelatihan penjelasan yang diberikan tentang penyusunan fenomena multi-akibat maupun soal multi-jawaban dapat saya ikuti (indikator 5)

11. Setelah mengikuti penjelasan, tergambar bagaimana cara menyusun fenomena multiakibat maupun soal multi-jawaban

12. Setelah mengikuti penjelasan, saya merasa dapat menyusun fenomena multi-akibat maupun soal multi-jawaban

Skor indikator 2 mencapai 3,57 (hampir sempurna 4,0) artinya hampir semua responden menyatakan sikap sangat setuju. Jadi fenomena dan soal multi jawaban memiliki hubungan sangat erat dengan pengembangan kemampuan berpikir tingkat tinggi.

Hubungan tersebut dapat dijelaskan sebagai berikut: Elemen berpikir tingkat tinggi mencakup kemampuan berpikir kritis, berpikir kreatif, dan beberapa berpikir tingkat tinggi lainnya. Pengembangan berpikir kritis antara lain difasilitasi dengan menyediakan potensi bagi pebelajar untuk menganalisis dan mengidentifikasi isu kunci yang menjadi isu bersama dalam berbagai bagian masalah yang disajikan. Selanjutnya, pengembangan kemampuan berpikir kreatif antara lain dapat difasilitasi dengan penggunaan fenomena dan soal yang memiliki lebih dari satu jawaban benar. Penggunaan fenomena ataupun soal jenis ini sejalan dengan pengembangan berpikir secara divergen.

Pembengambangan berpikir secara divergen itu sendiri sejalan dengan pengembangan berpikir model kausal dovergen, model kausal kombinasi sederhana, serta model kausal kombinasi berantai (Rokhmat, Marzuki, Hikmawati, \& Verawati, 2017; Rokhmat, Marzuki, Wahyudi, \& 
Putrie, 2019; serta Rokhmat, Marzuki, Kosim, \& Verawati, 2020). Selain itu, berpikir divergen juga sejalan dengan model tugas terbuka yang bermanfaat untuk mendorong kemampuan berpikir kreatif, khusuanya pada elemen kelancaran, fleksibilitas, dan/atau originalitas (Meyer \& Lederman, 2015). Selanjutnya, Anwar Aness, Khizatr dan Muhammad (2012) menyatakan bahwa model tugas terbuka selain mendorong ketiga elemen berpikir kreatif di atas, juga mendorong elaborasi.

Ketiga model tersebut (DCM, SCoCM dan ChCoCM) secara linier mendorong berpikir kreatif yang menunjukkan bahwa kelancaran, fleksibilitas dan/atau orisinalitas akan hasil dari tugas terbuka (Meyer \& Lederman, 2015). Namun, Anwar Aness, Khizatr dan Muhammad (2012) menyatakan bahwa selain ketiga efek tersebut, model juga mendorong elaborasi. Kefasihan menunjukkan berapa banyak jawaban seorang pelajar telah diprediksi, fleksibilitas terkait dengan bagaimana tingkat kesulitan yang tinggi telah dirancang, orisinalitas ditunjukkan dari tambahan jawaban yang ditulis oleh pembelajar dan, akhirnya, elaborasi ditunjukkan dari bagaimana peserta didik membangun ide-ide mereka. Selain itu, model juga memiliki kesamaan dengan strategi yang digunakan oleh Escudero dkk. (2009).

\section{Foto Kegiatan}

Paparan strategi pengembangan instrumen tes

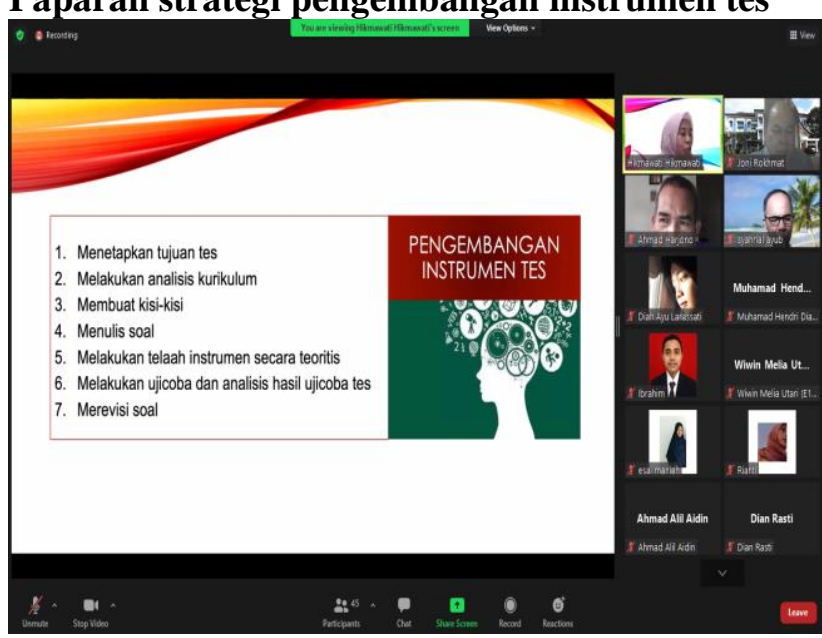

Kehadiran Tim \& Peserta dalam zoom

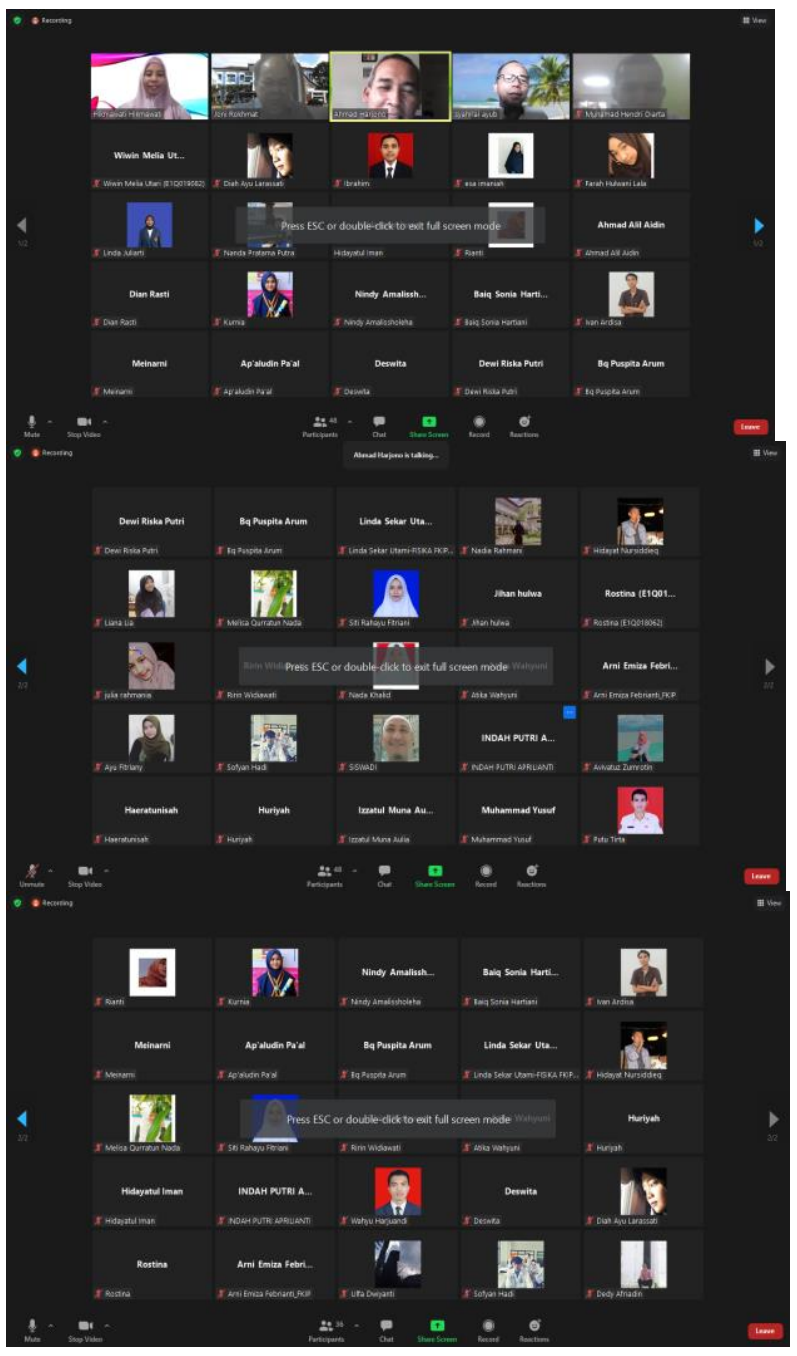

\section{Kesimpulan}

Kegiatan pengabdian kepada masyarakat dengan tema pelatihan pengembangan fenomena dan soal mutli jawaban telah dilaksanakan kepada mahasiswa tingkat akhir dan alumni program studi pendidikan fisika, FKIP, Universitas Mataram. Pengembangan fenomena dan soal multi akibat ini khususnya diorientasikan untuk mengingkatkan kemampuan pemecahan masalah dan berpikir kreatif. Hasil kegiatan menunjukkan bahwa metode pelatihan yang digunakan melalui media zoom adalah efektif. Terhadap seluruh pernyataan positif tentang pengembangan fenomena dan soal multi akibat yang dikaitkan dengan penguasaan konseptual materi ajar, pengembangan kemampuan pemecahan masalah, dan pengembangan kemampuan berpikir kreatif, serta saran untuk pengembangan lanjutan secara lateral pada seluruh disiplin ilmu dan secara vertikal pada semua jenjang pendidikan mendapat respon dari 
cenderung setuju (25\%) hingga sangat setuju $(75 \%)$.

\section{Saran}

Selanjutnya, sebagai rekomendasi atau saran, dapat dirangkum beberapa hal pentingnya sosialisasi pengembangan instrumen pembelajaran berbasis fenomena dan soal multi jawaban. Hal ini, khususnya jika dikaitkan dengan upaya pembelajaran yang menggunakan model kausalitik yang diorientasikan untuk meningkatkan kemampuan pemecahan masalah (Rokhmat dkk, 2020). Beberapa hal penting berkaitan pertanyaan mengapa fenomena dan soal multi jawaban perlu terus dikembangkan adalah sebagai berikut: 1) sangat diperlukan untuk mendukung berpikir tingkat tinggi, khususnya berpikir kritis dan kreatif, 2) sangat mendukung upaya penguasaan materi yang dipelajari secara konseptual, 3) model pemaparan materi yang disampaikan dalam sosialisasi adalah efektif berdasar pengakuan perserta yaitu menjadi memiliki pengetahuan dan merasa dapat mengembangkan fenomena maupun soal multi jawaban setelah selesai kegiata pengabdian, 4) tim pengabdian dan peserta sepakat bahwa model fenomena dan soal ini dikembangkan pada semua jenjang pendidikan, dan 5) berpikir tingkat tinggi juga direkomendasikan tim pengabdian dan peserta supaya diberikan kepada siswa sedini mungkin, serta dijadikan sebagai suatu pembiasaan dalam setiap kegiatan pembelajaran, serta terakhir 6) ini sebagai rekomendasi tambahan, yaitu bahwa model fenomena dan soal ini juga perlu dikembangkan secara lateral pada semua disiplin ilmu.

\section{Ucapan Terima Kasih}

Penulis mengucapkan terima kasih kepada Universitas Mataram melalui Lembaga Penelitian dan Pengabdian Masyarakat (LPPM) dan Fakultas Keguruan dan Ilmu Pendidikan (FFKIP) yang telah mendanai kegiatan ini, serta kepada mahasiswa tingkat akhir dan alumni program studi pendidikan fisika FKIP Unram yang telah berpartisipasi sebagai peserta dalam kegiatan pengabdian ini.

\section{Daftar Pustaka}

Anwar, M., N., Aness, M., Kizar, A., Naseer, M., \& Muhammad, G. (2012). Relationship of creative thinking with the academic achievements of secondary school students. International Interdisciplinary Journal of Education, 1(3), 44.

Gordon, J. R., McGrew, R. V., \& Serway, R. A. (2010). Physics for Scientists and Engineers, eighth edition volume 1 . USA: Cengage Learning, Inc. Halliday, D. \& Resnick, R. (1978). Physics part 1 \& 2, Third Edition. Canada: John Wiley $\&$ Sons. Inc.

Meyer, A. A., \& Lederman, N. G. (2015). Creative cognition on secondary science: An exploration of divergent thinking in science among adolescents. International Journal of Science Education. Retrieved from http://dx.doi.org/10 $.1080 / 09500693.2015 .1043599$

Makmur \& Thaiher R. 2015. Human Innovation and Creativity in Administration and Management. Bandung: PT. Refika Aditama.

Nasir, Muhamad. 2015. Peraturan Menteri Riset, Teknologi, dan Pendidikan Tinggi Republik Indonesia Nomor 44.

Podolefsky, N., (2004). The Use of Analogy in Physics Learning and Instruction. University of Colorado.

Rokhmat, J., (2014). Penggunaan Paradigma GayaReaksi dan Pendekatan Analogi untuk Meningkatkan Pemahaman Konsep Gaya Gesek bagi Mahasiswa Calon Guru Fisika (Studi Kasus Perkuliahan Fisika Dasar I). Journal Pijar MIPA, Vol IX No. 2, September 56-61.

Rokhmat, Marzuki, Hikmawati, \& Verawati (2017). The Causal Model in Physics Learning with a Causalitic-thinking Approach to Increase the Problem-solving Ability of Pre-service Teachers. Pertanika Journal of Social Sciences and Humanities Vol 25(S), p. 153-168.

Rokhmat, Marzuki, Wahyudi, \& Putrie (2019). A Strategy of Scaffolding Development to Increase Students' Problem-Solving Abilities: The Case of Physics Learning with Causalitic-Thinking Approach. 
Journal of Turkish Science Education, Vol. 16(4), p. 569-579

Rokhmat, Marzuki, Kosim, \& Verawati (2020). The causalitic learning model to increase students' problem-solving ability. Journal of Physcis: Conference Series, 1572 012068, p. 1-19.

Sambada, D. 2012. Peranan Kreativitas Siswa Terhadap Kemampuan Memecahkan Masalah Fisika dalam Pembelajaran Kontekstual. Jurnal Penelitian Fisika dan Aplikasinya (JPFA), 2(2), 37-47.

Rokhmat, J. (2017). Fisika Dasar dengan Pendekatan Berpikir Kausalitik. Lombok Barat: PT Arga Puji Press.

Tipler, P. A. \& Mosca, G.(2008). Physics for Scientists and Engineers, Sixth edition. New York: W H Freeman and Company. 